\title{
Davi e Salomão: A utopia da grandeza e da unidade em Israel
}

\author{
Orientador: Prof ${ }^{a}$ Maria de Lourdes Corrêa Lima
}

Pesquisadora: Michel Alves dos Santos

\section{Fonte: CNPq}

\section{Introdução}

Segundo as tradições bíblicas, após a morte de Saul (1030-1010), as tribos de Israel e Judá que não conheciam, como os povos à sua volta, o esquema de sucessão dinástica, entram em crise. É neste contexto que ganha destaque a figura de Davi (1010-970), o jovem líder belemita, que no passado trabalhara sob o comando de Saul, mas que havia sido banido de Israel e fora perseguido pelo rei, ao ponto de um dado momento da vida ter que se unir aos filisteus e tornar-se seu vassalo.

Davi e seu filho Salomão (970-931) teriam possibilitado a manutenção e a continuidade do regime monárquico em Israel. Davi conseguiu, segundo o relato bíblico, governar "sobre todo Israel e Judá" (2Sm 5,3). Conquistou a cidade jebusita de Jerusalém, a qual transformou em sede do seu reinado, bem como para lá transferiu a "Arca da Aliança" e, assim, fez de Jerusalém uma cidade com o santuário nacional dedicado ao Deus de Israel. Davi também teria estendido o seu domínio para além das fronteiras das doze tribos de Israel, bem como conquistado um enorme território à sua volta, expulsando a ameaça filistéia. Em suma, Davi teria transformado Israel em uma grande potência.

Essas mudanças ocorridas em Israel teriam sido mantidas, após a morte de Davi, por seu filho Salomão. Este rei destacou-se não tanto pelas guerras, mas pela sua capacidade administrativa. Salomão teria sido o responsável pela formação de um corpo burocrático em Israel. O sábio e justo rei consolidou o reino criado por seu pai. Ele construiu um Templo majestoso para YHWH, próximo ao seu palácio, fazendo do templo a sua capela real. Com seus casamentos, Salomão estabeleceu alianças com os povos vizinhos. Ele 
também teria estimulado o comércio de Israel com outros povos e construído um famoso estábulo real em Meguido. Sob o seu reinado, a fama de Israel ter-se-ia espalhado.

Com a descoberta de achados arqueológicos em Meguido, Hazor e Gezer entre o início e meados do século XX da era cristã, essa visão acerca da monarquia unida de Israel ganhou impulso. A história bíblica encontrou respaldo na arqueologia.

Contudo, nos tempos mais recentes, graças às novas descobertas arqueológicas, a história da monarquia unida passou por um grande questionamento, que trouxe uma reviravolta à idéia que se tinha a respeito deste período. As novas descobertas trouxeram consigo o desafio de se repensar a História de Israel, bem como o pensamento teológico que a norteia. Descobriu-se que o período de ouro da monarquia israelita não teve as grandes conquistas que se pensava. Davi não teria reinado senão sobre três tribos (Judá, Efraim e Benjamim) [1]. As grandes obras atribuídas a Salomão na realidade terão sido realizadas dois séculos após este rei. O Israel do período áureo não passava de um conjunto de vilas esparsas.

\section{Objetivos}

A presente pesquisa buscou compreender melhor a visão tradicional acerca do Reino Unido de Israel. O estudo também procurou entender o projeto teológico e político que se esconde por detrás da imagem grandiosa criada acerca dos inícios da monarquia em Israel. A Departamento de Teologia pesquisa ainda procurou, de alguma forma, entender, retirada a roupagem lendária dasmonarquias de Davi e Salomão, a real configuração do Israel do século X. 